\title{
Loss of Cytochrome Oxidase in Saccharomyces cerevisiae during Inhibition of Mitochondrial Protein Synthesis by Erythromycin and Chloramphenicol
}

\author{
By A. B. STONE AND D. WILKIE \\ Department of Botany and Microbiology, \\ University College London, London WC I E $6 B T$
}

(Received 9 April 1975; revised 26 May 1975)

\begin{abstract}
SUMMARY
There is a major reduction in respiratory competence, and inhibition of growth, several hours after the addition of erythromycin or chloramphenicol to Saccharomyces cerevisiae growing in medium containing a non-fermentable carbon source. Spectrographic evidence is presented for a loss of cytochrome oxidase as a consequence of the antibiotic treatment. This loss is prevented by cyanide or oligomycin. When glucose is added, however, the loss occurs irrespective of the presence of the respiratory inhibitors. Cycloheximide does not affect respiratory competence or cause loss of cytochrome oxidase, and it prevents the loss elicited by erythromycin if both compounds are added together. However, if cycloheximide is added some time after the addition of erythromycin, it fails to block the response to the latter drug. The results cannot be accounted for on the basis of the segregation of a finite number of mitochondria into an increasing number of progeny cells but, rather, suggest that the mitochondria are modified during growth in chloramphenicol or erythromycin.
\end{abstract}

\section{INTRODUCTION}

The antibiotics chloramphenicol and erythromycin specifically inhibit protein synthesis in bacteria, mitochondria and chloroplasts by interference with the ribosomes, while the cytoplasmic ribosomes of eukaryotes are resistant to these drugs (Wintersberger, 1965; Lamb, Clark-Walker \& Linnane, 1968; Borst \& Grivell, 197I). Such agents inhibit the growth of the facultative anaerobe Saccharomyces cerevisiae growing aerobically on nonfermentable substrates (e.g. glycerol), that is when using the mitochondrial respiratory system, but do not inhibit growth on fermentable substrates (e.g. glucose). We studied events leading to the arrest of growth of this organism in a glycerol medium containing one or other of these antibiotics. Both compounds prevent the synthesis of cytochrome oxidase (cytochrome $a a_{3}$ ) and cytochrome $b$ (Tzagoloff, Rubin \& Sierra, 1973; Mahler \& Perlman, I97I), but the fate of the pre-existing cytochromes when mitochondrial protein synthesis is blocked has not been considered. We present evidence that under these conditions cytochrome oxidase is lost and there is a drop in respiratory competence. 


\section{METHODS}

Organisms. Haploid strains D6 and A7F of S. cerevisiae from this laboratory were used.

Cultural conditions. Organisms were grown in yeast extract medium (I \%, w/v; Difco) supplemented with glycerol $(4 \%, \mathrm{w} / \mathrm{v})$, to exponential phase in shake cultures (I l) at $30{ }^{\circ} \mathrm{C}$. Growth was measured with an EEL colorimeter, using filter OGRI, and correcting for non-linear response; Io EEL units are equivalent to $20 \mathrm{mg}$ wet wt cells $/ \mathrm{ml}$.

Chemicals. The sources of antibiotics were: chloramphenicol, Parke, Davis and Co., Hounslow, Middlesex; cycloheximide, Koch-Light; erythromycin, Abbot Laboratories Ltd, Queenborough, Kent; oligomycin, Sigma.

Cytochrome absorption spectra. Organisms from $150 \mathrm{ml}$ culture were washed twice with $\mathrm{I} \%(\mathrm{w} / \mathrm{v}) \mathrm{NaCl}$, mixed with about $\mathrm{IO} \mathrm{mg}$ sodium dithionite as reducing agent, and suspended in distilled water to a final volume of $\mathrm{I} \cdot 3 \mathrm{ml}$. Absorption spectra were obtained at room temperature, using a Unicam SP 1800 recording spectrophotometer. To obtain an approximate estimate of changes in the relative amounts of cytochromes, the areas of the different absorption peaks were related by weighing copies on heavy tracing fabric of the areas. In general, the cytochrome $c$ peak and its shoulder, representing cytochrome $b$, were weighed together. In some experiments, washed cells were first resuspended in tris- $\mathrm{HCl}$ buffer $(0.05 \mathrm{M}, \mathrm{pH} 8.0)$ containing glycerol $(15 \%, \mathrm{w} / \mathrm{v})$, then frozen in dry ice - acetone and broken by crushing in a pre-cooled Eaton press (Eaton, 1962) in order to exclude the possibility that dithionite was penetrating inefficiently and, therefore, failing completely to reduce the cytochromes.

Measurement of respiratory activity. Intact, washed cells from $10 \mathrm{ml}$ culture were resuspended at about $10^{6} / \mathrm{ml}$ in sodium phosphate buffer ( $(0.1 \mathrm{mM}, \mathrm{pH} 6 \cdot 8)$ containing sodium succinate $(0.5 \mathrm{~mm})$, a substrate readily available to intact yeast cells (Hughes \& Wilkie, 1970). Cyanide-sensitive oxygen uptake $(50 \mu \mathrm{g} \mathrm{KCN} / \mathrm{ml})$ was measured polarographically in a Clark-type oxygen electrode coupled to a pen recorder.

Cell viability. Colony-forming units were compared with total cells plated, as measured in the haemocytometer.

\section{RESULTS}

Effect of erythromycin and chloramphenicol on growth, respiratory competence and cytochrome absorption spectrum

When either antibiotic was added at $\mathrm{I} \mathrm{mg} / \mathrm{ml}$ to yeast growing in a glycerol medium, growth continued at approximately the normal rate for $5 \mathrm{~h}$, slowed down over the next $3 \mathrm{~h}$, then stopped; the cell mass increased by a factor of about 2.5 (Table I). Respiratory competence, measured as the rate of oxygen uptake using a series of equal culture volumes, greatly decreased (Table I). Spectra of suspensions of intact cells, derived from a series of equal volumes of culture taken at various times during these experiments, showed that in the presence of the drugs there was a fall in the characteristic absorption peak of cytochrome oxidase at $605 \mathrm{~nm}$. After a somewhat variable time (Io to $20 \mathrm{~h}$ ), this peak had virtually disappeared (Table $\mathrm{I}$ ). The same results were obtained in several independent experiments. There was no induction of the petite condition, i.e. mitochondrial mutation to respiratory deficiency. This is in contrast to the result of erythromycin or chloramphenicol treatment in fermentable medium, where growth continues and petite mutants appear after several generations (Williamson, Maroudas \& Wilkie, 197I). Cell viability was unaffected during the course of the present experiments.

A series of absorption spectra demonstrated that the loss of cytochrome oxidase was 
Table I. Effect of erythromycin, chloramphenicol and cycloheximide on the respiratory competence and cytochrome spectrum of S. cerevisiae D6 incubated in glycerol medium

\begin{tabular}{|c|c|c|c|c|c|}
\hline & \multirow{2}{*}{$\begin{array}{l}\text { Time after } \\
\text { addition } \\
\text { of drug (h) }\end{array}$} & \multirow{2}{*}{$\begin{array}{c}\text { Oxygen } \\
\text { uptake* } \\
(\%)\end{array}$} & \multicolumn{2}{|c|}{ Cytochrome spectrum $\dagger$} & \multirow{2}{*}{$\begin{array}{c}\text { Growth } \\
(\Delta E \ddagger)\end{array}$} \\
\hline & & & $a$ & $\overrightarrow{b+c}$ & \\
\hline $\begin{array}{l}\text { Initial culture } \\
\text { Antibiotics added }\end{array}$ & 0 & 100 & 108 & 322 & 一 \\
\hline None (control) & $\begin{array}{l}10 \cdot 0 \\
18.0\end{array}$ & $\begin{array}{l}280 \\
\text { ND }\end{array}$ & $\begin{array}{l}\text { ND } \\
346\end{array}$ & $\begin{array}{l}\text { ND } \\
995\end{array}$ & $\begin{array}{r}8.5 \\
10 \cdot 5\end{array}$ \\
\hline Erythromycin ( $1 \mathrm{mg} / \mathrm{ml})$ & $\begin{array}{l}10 \cdot 0 \\
12 \cdot 0 \\
14 \cdot 5 \\
18.0\end{array}$ & $\begin{array}{l}54 \\
37 \\
24 \\
10\end{array}$ & $\begin{array}{r}29 \\
\text { ND } \\
\text { ND } \\
\text { I }\end{array}$ & $\begin{array}{l}787 \\
\text { ND } \\
\text { ND } \\
906\end{array}$ & $\begin{array}{l}2.5 \\
2.5 \\
2.5 \\
2.5\end{array}$ \\
\hline $\begin{array}{l}\text { Chloramphenicol } \\
\text { (I } \mathrm{mg} / \mathrm{ml} \text { ) }\end{array}$ & $\begin{array}{l}10 \cdot 0 \\
12 \cdot 0 \\
14 \cdot 5 \\
18.0\end{array}$ & $\begin{array}{l}55 \\
28 \\
19 \\
13\end{array}$ & $\begin{array}{r}24 \\
\text { ND } \\
\text { ND } \\
2\end{array}$ & $\begin{array}{r}856 \\
\text { ND } \\
\text { ND } \\
803\end{array}$ & $\begin{array}{l}2.5 \\
2.5 \\
2.5 \\
2.5\end{array}$ \\
\hline $\begin{array}{l}\text { Cycloheximide } \\
(50 \mu \mathrm{g} / \mathrm{ml})\end{array}$ & $\begin{array}{r}8 \cdot 0 \\
40 \cdot 0\end{array}$ & $\begin{array}{l}90 \\
67\end{array}$ & $\begin{array}{l}92 \\
98\end{array}$ & $\begin{array}{l}290 \\
284\end{array}$ & $\begin{array}{l}0.5 \\
0.5\end{array}$ \\
\hline
\end{tabular}

ND, Not determined.

* Relative to that in the initial culture, of $46 \mathrm{nmol} \mathrm{O}_{2} / \mathrm{min} / 10^{6}$ cells.

$\dagger$ Relative areas of the absorption peaks.

$\ddagger$ Increase in extinction, relative to time zero.

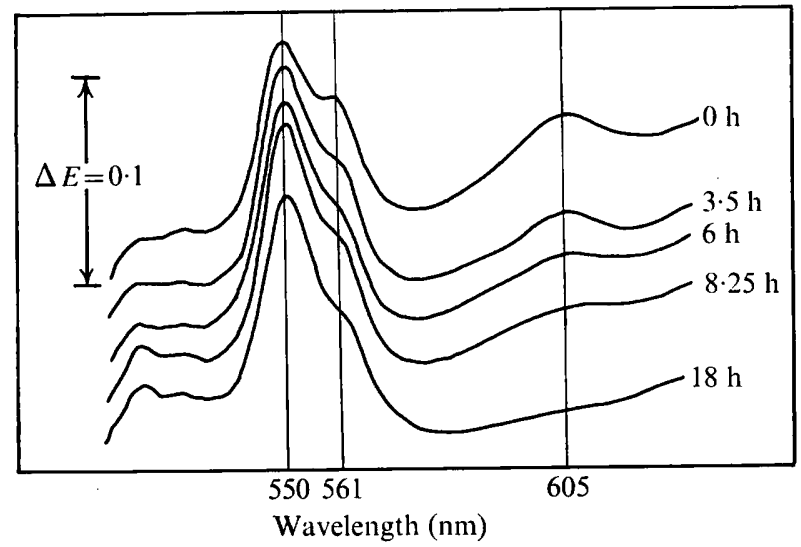

Fig. I. Effect of erythromycin (I $\mathrm{mg} / \mathrm{ml}$ ) on the cytochrome spectrum of $S$. cerevisiae $\mathrm{D} 6$ grown in glycerol medium. Absorption spectra were obtained with cells from a series of equal volumes of the culture taken at the indicated times; the maxima at 550, 56I and $605 \mathrm{~nm}$ represent the $\alpha$ absorption peaks of the reduced forms of cytochrome $c$, cytochrome $b$ and cytochrome oxidase, respectively.

gradual and began soon after the addition of erythromycin (Fig. I). The decrease in the $605 \mathrm{~nm}$ absorption peak was not due to a failure of sodium dithionite to penetrate efficiently, because identical spectra were observed when cells were broken with an Eaton press before the addition of this compound. The absorption of cytochrome $b$ at $56 \mathrm{I} \mathrm{nm}$ was difficult to measure due to its overlap with the relatively large, and increasing, cytochrome $c$ peak at $550 \mathrm{~nm}$, but it is evident from Fig. I (and from Fig. 2) that some cytochrome $b$ persisted even after many hours in erythromycin, when no cytochrome oxidase absorption was detectable. These findings applied to both of the yeast strains studied, D6 and $A 7 F$. 


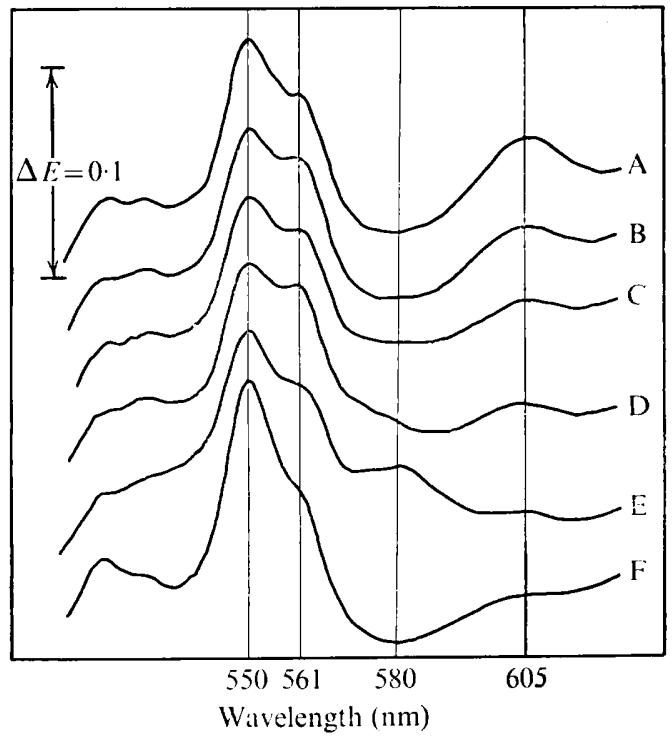

Fig. 2. Effect of the delayed addition of cycloheximide $(50 \mu \mathrm{g} / \mathrm{ml})$ on the cytochrome absorption spectrum of $S$. cerevisiae $\mathrm{D} 6$ incubated for $\mathrm{I} 5 \mathrm{~h}$ in glycerol medium containing erythromycin ( $\mathrm{mg} / \mathrm{ml}$ ). At zero time, an initial control portion (A) was taken, and erythromycin was added to the remaining culture. Cycloheximide was added to portions of this at (B), o h, (C) $0.5 \mathrm{~h}$, (D) I. $5 \mathrm{~h}$ and (E) $3 \mathrm{~h}$, and spectra were obtained at $15 \mathrm{~h}$; (F) erythromycin alone.

The budding of individual cells micromanipulated on to agar with or without erythromycin (I $\mathrm{mg} / \mathrm{ml}$ ) was studied. The first bud appeared after about $2 \mathrm{~h}$, whether the drug was present or not. However, second-generation buds were significantly slower to develop in the presence of the drug, and on average only one more daughter cell was produced, resulting in clones of about five cells. These cells usually remained attached to the parent cell and the later-formed buds tended to be relatively small. This result is in tolerable agreement with growth measurements in liquid medium.

\section{Effect of cycloheximide}

Cycloheximide blocks cytoplasmic protein synthesis in eukaryotes due to its affinity for cytoplasmic ribosomes; it has no direct effect on mitochondrial protein synthesis (Lamb et al. 1968). When this drug (at $50 \mu \mathrm{g} / \mathrm{ml}$, as in Table $\mathrm{I}$, or at $300 \mu \mathrm{g} / \mathrm{ml}$ ) was used in place of erythromycin in experiments similar to that described above, the extinction of the culture increased by $50 \%$ during the first $6 \mathrm{~h}$. This was the result of cell swelling rather than budding; microscopy showed that budding was totally blocked by cycloheximide. However, the inhibition of cytoplasmic protein synthesis reduced respiratory competence by a mere $33 \%$ over $40 \mathrm{~h}$ (although the cells were dead by then), and the cytochrome spectrum was virtually unchanged.

\section{Effect of addition of cycloheximide during erythromycin treatment}

If erythromycin and cycloheximide were added together, the loss of the cytochromeoxidase spectrum normally elicited by the former drug (Fig. 2 F) did not occur (Fig. 2 B), and respiratory competence fell by only $32 \%$ over $\mathrm{I} 5 \mathrm{~h}$. However, if the culture was inhibited for a short period by erythromycin alone, then cycloheximide did not prevent the subsequent disappearance of the $605 \mathrm{~nm}$ absorption peak. A delay of 0.5 to I $5 \mathrm{~h}$ (Fig. $2 \mathrm{C}, \mathrm{D})$ before the addition of cycloheximide permitted some reduction during the ensuing $14 \mathrm{~h}$, 
Table 2. Effect of erythromycin (I $m g / m l)$ on $S$. cerevisiae strain D6 incubated in glycerol medium containing glucose

Glucose (to $0.2 \%$ ) was added every $4 \mathrm{~h}$ to maintain a supply of fermentable substrate.

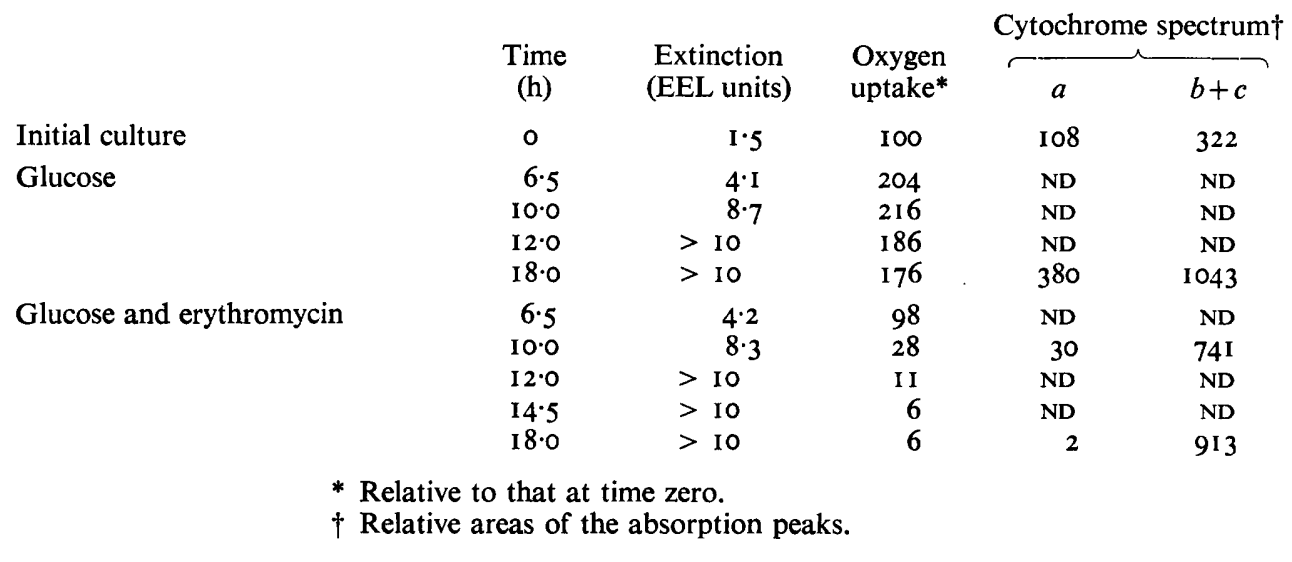

and a delay of $3 \mathrm{~h}$ allowed its complete loss (Fig. $2 \mathrm{E}$ ), accompanied by an $86 \%$ drop in respiratory competence. In these three cultures, material absorbing maximally at $580 \mathrm{~nm}$ appeared, and was quite distinct from the cytochrome-oxidase maximum. The nature and origin of this product are unknown.

\section{Effect of glucose, oligomycin and cyanide}

To see whether the effect of erythromycin was caused merely by a drop in the amount of available energy, glucose (to $0.2 \%$ final concentration) was added initially to the glycerol medium and added subsequently every $4 \mathrm{~h}$. This was found to maintain growth in the presence of erythromycin. Glycolysis is known to provide adequate intramitochondrial ATP to maintain, for example, mitochondrial nucleic acid synthesis in respiration-deficient petite mutants (Borst, I972), and mitochondrial DNA replication proceeds for several generations in yeast growing in glucose medium in the presence of erythromycin (Williamson et al. 197I). In control cultures containing this low glucose concentration, the growth rate, cytochrome content and respiratory activity were comparable to those in cultures with glycerol alone (Table 2; compare with Table I). Although glucose permitted the cells to continue dividing in the presence of erythromycin, it was found that a fall in respiratory competence and a loss of the cytochrome-oxidase spectrum took place, as in the absence of glucose (Table 2). Furthermore, in the absence of glucose, if, instead of adding erythromycin, the supply of ATP was blocked by $10 \mu \mathrm{g}$ oligomycin $/ \mathrm{ml}$ or $50 \mu \mathrm{g}$ cyanide $/ \mathrm{ml}$, the cytochrome-oxidase peak persisted (Table 3). This Table also shows that cyanide prevented the loss of the cytochrome-oxidase spectrum normally caused by erythromycin. However, when $0.2 \%$ glucose was also present, the cells were able to grow and the cytochrome peak disappeared. With cyanide, erythromycin and glucose, the loss of cytochrome oxidase was prevented by the addition of cycloheximide at zero time. This series of experiments suggests that the loss of cytochrome oxidase depends on respiration only inasmuch as this is a requirement for cytoplasmic protein synthesis if no fermentable substrate is present. 
Table 3. Effect of erythromycin, cycloheximide, respiratory inhibitors and glucose on the cytochrome spectrum of $S$. cerevisiae $\mathrm{D} 6$ incubated in glycerol medium

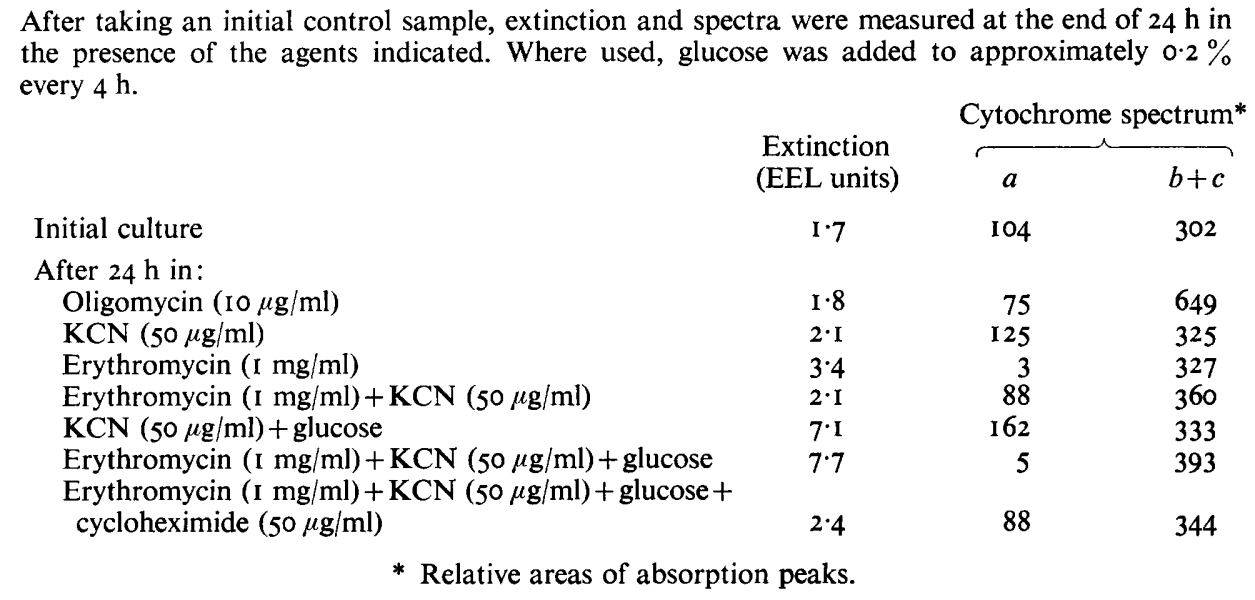

\section{DISCUSSION}

Drugs which are known specifically to block mitochondrial protein synthesis (see Stone \& Wilkie, 1974), when added to yeast metabolizing a non-fermentable substrate, stopped growth after one or two cell divisions, while there was a dramatic reduction in the ability to take up oxygen. This cannot be explained by the segregation of a finite number of mitochondria into an increasing number of cells. Our data suggest, rather, that these effects can be accounted for by a loss of cytochrome oxidase, the terminal component of the respiratory chain. Preliminary evidence from electron microscopy indicates accompanying degradative changes in mitochondrial inner membrane structure.

Mitochondrial protein synthesis is required for the assembly of at least four structures which form an integral part of the mitochondrion's inner membrane. These include cytochrome oxidase, three of whose seven polypeptide subunits are made on the mitochondrial ribosomes (Tzagoloff et al. 1973; Mason \& Schatz, 1973), as well as cytochrome $b$ (Mahler \& Perlman, 197I), and oligomycin-sensitive ATPase (Tzagoloff et al. 1973). Other proteins may also be involved. Cytochrome $c$ is manufactured by the cytoplasmic system (Sherman, Taber \& Campbell, I965). This explains why erythromycin and chloramphenicol block the formation of cytochrome oxidase and cytochrome $b$ while permitting an increase in cytochrome $c$. But it is difficult to see why this should lead to the disappearance of the preexisting cytochrome oxidase. If the phenomenon reflects protein turnover in the inhibited mitochondrion, it does not result merely from an insufficiency of energy for normal maintenance because it is just as pronounced when erythromycin is added in the presence of glucose, which supplies adequate intra-mitochondrial ATP for macromolecular synthesis (Williamson et al. 1971; Borst, 1972). Turnover of cytochrome oxidase may nevertheless be involved, and its prevention by cycloheximide may indicate the need for the synthesis of a labile peptidase, as proposed for tyrosine transaminase turnover in rat liver (Kenney, 1967). However, cycloheximide does not prevent the loss of cytochrome oxidase if it is added 2 to $3 \mathrm{~h}$ after the addition of erythromycin. This suggests that either the relevant cytoplasmic proteins, once made, persist, or they initially modify the environment of cytochrome oxidase so that it becomes susceptible to other factors. 
We thank Mrs S. Mahadevaiah for skilful technical assistance. This work was partially supported by a grant to A.B.S. from the U.K. Medical Research Council.

\section{REFERENCES}

Borst, P. (1972). Mitochondrial nucleic acids. Annual Review of Biochemistry 41, 333-376.

Borst, P. \& Grivell, L. A. (1971). Mitochondria ribosomes. FEBS Letters 13, 73-88.

Eaton, N. R. (1962). New press for disruption of microorganisms. Journal of Bacteriology 83, 1359-1360.

Hughes, A. R. \& WILKIE, D. (1970). Preferential inhibition of respiration in Saccharomyces cerevisiae by chlorimipramine: correlation with chlorpromazine. Biochemical Pharmacology 19, 2555-2560.

KeNNEY, F. T. (1967). Turnover of rat liver tyrosine transaminase: stabilization after inhibition of protein synthesis. Science, New York 156, 525-528.

Lamb, A. J., Clark-Walker, G. D. \& Linnane, A. W. (1968). The biogenesis of mitochondria. IV. The differentiation of mitochondrial and cytoplasmic protein synthesizing systems in vitro by antibiotics. Biochimica et biophysica acta 161, 415-427.

Mahler, H. R. \& Perlman, P. S. (1971). Mitochondriogenesis analysed by blocks on mitochondrial translation and transcription. Biochemistry Io, 2979-2990.

Mason, T. L. \& Schatz, G. (1973). Cytochrome c oxidase from baker's yeast. II. Site of translation of the protein components. Journal of Biological Chemistry 248, 1355-1 360.

Sherman, F., TABer, H. \& CAMpbell, W. (I965). Genetic determination of iso-cytochromes $c$ in yeast. Journal of Molecular Biology 13, 21-39.

Stone, A. B. \& WILKIE, D. (1974). Cellular and mitochondrial effects of folate antagonism by pyrimethamine in Saccharomyces cerevisiae. Journal of General Microbiology 83, 283-293.

Tzagoloff, A., Rubin, M. S. \& SierRa, M. F. (1973). Biosynthesis of mitochondrial enzymes. Biochimica et biophysica acta 301, 7I-I04.

Williamson, D. H., Maroudas, N. \& Wilkie, D. (I97I). Induction of the cytoplasmic petite mutation in Saccharomyces cerevisiae by antibacterial antibiotics. Molecular and General Genetics 111, 209-223.

Wintersberger, E. (1965). Proteinsynthese in isolierten Hefe-Mitochondrien. Biochemische Zeitschrift 34I, 409-419. 